\title{
Afetlerde Sosyal Medya Kullanımı ve Etik İkilemler: İzmir Seferihisar Depremi Örneği
}

\author{
Ertuğrul Usta' ${ }^{1}$, Mustafa YÜKSELER ${ }^{2}$
}

\section{Özet}

21. yüzyılda afetlerin sayısındaki artışlar, bütünleşik afet yönetimini ve disiplinlerarası çalıșmaları gerektirmektedir. Bu disiplinlerden biri olan medyanın farkındalık oluşturma ve bilgi paylaşımı gibi yükümlülükleri bulunmaktadır. Son yüzyll itibariyle web teknolojilerindeki gelişmeler, geleneksel medyadan farklı olanaklar sunan sosyal medyayı ortaya çıkarmışıı. Sosyal medyanın interaktif yapısı ve kamuoyuyla etkileşimi, dayanışma ve yardımlaşma ortamları sağlaması gibi afetlerdeki olumlu etkileriyle birlikte etik problemlere yol açabilen olumsuz etkileri de olabilmektedir. Çalıșmamızda, 30 Ekim 2020 tarihinde İzmir Seferihisar açılklarında meydana gelen deprem sonrası, sosyal medya platformlarında yapılan paylaşımlar ve haber içerikleri, medya ve etik konularında düzenlenen ulusal ve uluslararası metinler baz alınarak değerlendirilmiștir. Yapılan değerlendirme sonucunda, afet ve acil durumlar sonrasında geleneksel ve sosyal medya paylașım ve haber içeriklerinin hukuksal boyutta özel hayatın gizliliği, kişisel verilerin korunması gibi kişisel hakların yanında, etik boyutta haber öznesinin hassas durumu göz ardı edilerek oluşturulabildiği, herhangi bir süzgeçten geçmeden yayılarak afetin yönetimini zorlaştırabildiği görülmektedir. Bu sebeple, afet müdahale planlamaları içerisinde bu alana yönelik afet medya yönetimi planı oluşturulması, afet ve acil durumlarda medya kullanımına özgü rehber ilke ve kılavuzlar geliştirilmesi, halkın kriz durumlarında medya araçları kullanımı konusundaki farkındalık seviyesinin geliștirilmesi, mevzuat altyapısının hazırlanması gibi düzenleyici hazırlıkların yapılması gerekmektedir.

Anahtar Kelimeler: Afetlerde İletişim, Sosyal Medya, Etik, İzmir Seferihisar Depremi

\section{The Use of Social Media and Ethical Dilemmas in Disaster: The Case of Earthquake in İzmir, Seferihisar}

\begin{abstract}
The increase in the numbers of disasters in the 21st century requires integrated disaster management and interdisciplinary studies. The media, as one of these disciplines, plays an important role in raising

\footnotetext{
${ }^{1}$ Sosyal Hizmet Uzmanı, İzmir Afet ve Acil Durum Müdürlüğü, İzmir e-posta/e-mail: ertugrul.usta@afad.gov.tr ORCID No: 0000-0002-9482-5729

2 Öğretim Görevlisi, Mülkiyet Koruma ve Güvenlik Bölümü, Kavaklıdere MYO, Muğla Sıtkı Koçman Üniversitesi, Muğla İlgili yazar e-posta/ Corresponding author e-mail: mustafayukseler@mu.edu.tr ORCID No: 0000-0003-3644-3295
} 
awareness and sharing information. Since the last century, developments in web technologies have created social media that offers different opportunities than the traditional media. Along with the positive effects of using the social media during disasters, such as its interactive nature and active interaction with the public, it can also have negative effects that can lead to ethical problems. After the earthquake in Izmir, Seferihisar, on October 30,2020, the shares and news content on social media platforms were evaluated for our study, on the basis of national and international texts on media and ethics. The result of the evaluation was that traditional and social media's news content can be created by ignoring the ethically sensitive nature of the news, as well as ignoring the personal rights of the people being involved, such as the right of privacy and protection of personal data after disasters or emergencies; and the way they spread without any filters, thus making the disaster management more difficult. For this reason, regulatory preparations such as creating a disaster media management plan, developing guidelines specific for the use of media in disaster or emergency situations, improving the awareness of the public on the use of media tools in crisis, and preparing the infrastructure for upcoming situation as such would be of great importance.

Keywords: Communication in Disasters, Social Media, Ethic, İzmir Seferihisar Earthquake

\section{GİRIŞ̧}

21. yüzyıl itibariyle dünya, Amerika Birleşik Devletleri'ndeki (ABD) 11 Eylül Saldırıları, Estonya'daki siber saldırılar, Katrina Kasırgası, Haiti ve Asya ülkelerindeki depremler, 2011 yılında Japonya'daki deprem, tsunami ve Fukushima Daiichi nükleer santral kazası, Avrupa'da görülen aşırı soğuk kıșlar, Suriye Krizi, COVID-19 Pandemisi gibi bir dizi doğa ve insan kaynaklı afetlerle sarsılmıştır. Bunların yanı sıra iklim değişikliği kaynaklı hem iklim göçleri ve iklim mülteciliği hem de sel, taşkın, kuraklık ve çölleşme gibi afetlerin sayısı ve şiddetinde artışlar olmuştur. Uluslararası Afetler Veri Tabanın [EM-DAT], 2000-2019 yılları arasında dünya çapında kaydettiği 7,348 afet olayından dolayı, yılda ortalama 60.000 olmak üzere toplamda yaklașık 1.23 milyon kişi hayatını kaybetmiş, dünya çapında 4 milyardan fazla insan etkilenmiş ve yaklaşık 2,97 trilyon ABD Doları ekonomik kayıp meydana gelmiştir. Ayrıca çalışmada, önceki 20 yıllık dönem (1980-1999) ile 2000-2019 yılları arasında EM-DAT tarafından kaydedilen afetler kıyaslandığında, afet sayısında bir artışın olduğu görülmektedir. Buna göre, 1980-1999 yılları arasında dünya çapında doğal tehlikelerle bağlantılı 4212 afet kaydedilirken, bu afetlerin 1.19 milyon kişinin hayatını kaybetmesine, 4 milyardan fazla insanın etkilenmesine ve 1.63 trilyon ABD doları ekonomik kaybın yaşanmasına neden olduğu belirtilmektedir (URL 1). Afetlerin tüm dünya üzerindeki bu etkileri ve iklim değişiklikleri göz önünde bulundurulduğunda, afetlerin yaşanma sıklığı ve şiddetinin arttığı ve günümüz dünya koşullarında gelecekte de artacağı söylenebilir.

Afetlerden sonra oluşan kriz ve kaos ortamının belirgin hale gelen özelliklerinden biri de iletişim sorunlarının yaşanmasıdır (Baechler, 2018). Afetlerde iletişimde, medya en önemli bilgi kaynaklarından biri olup, toplumun ve hükümetin tehlikelere ve afetlere bakışlarını, algılayışını ve tepkilerini önemli ölçüde etkilemekte veya şekillendirmektedir (Rodriguez, Diaz, Santos \& Aguirre, 2007). Medyanın afet iletişimindeki kapsamı, genel olarak tek bir kaynaktan çıkması ve geniş kitlelere mesajlar içermesiyle sınırlı olması, izleyici tepkisi ve katılımı için sınırlı fırsatlar sunmaktadır (Houston et al, 2014). Ancak bu etkilere karşı, sosyal medya gibi yeni iletişim teknolojilerinin evrimi, iki yönlü iletişim için daha fazla fırsatlar sunmaktadır (Fraustino, Liu \& Jin, 2012). Dünyadaki dijital verilerin hem yıllık hem aylık bazda raporlarını yayınlayan We Are Social şirketinin Ocak 2020 raporuna göre, dünya çapında 4.54 milyar kişinin internet ve 3.8 milyar kişinin sosyal medya kullandığı belirtilmiştir. Ayrıca çalışmada bu rakamlar 2019 yılının verileri ile karşılaştırılmış ve internet kullanımında \%7'lik bir artışın olduğu, sosyal medya kullanımında ise \%'luk bir artışın olduğu görülmüştür (URL 2). 21. yüzyıl itibariyle internet ve web teknolojilerinin hızla gelişmesi ve kullanımının giderek artması ile sosyal medyanın afetlerde iletişimde, bireylerin afet bilgileri, tutumları ve davranışlarının olumlu ve olumsuz yönde etkilemede güçlü bir araç olduğu söylenebilir. Nitekim araştırmalar, afetlerden sonra etkilenen insanlara bağıșta bulunmak (URL 3; Gao, Wang, Barberier \& Liu, 2011; Lobb, Mock \& Hutchinson, 
2012), yapılacak çalışmalara gönüllü olmak ve bilgi tabanlı destek sağlamak (Bird, Ling \& Haynes, 2012; Peary, Shaw \& Takeuchi, 2012), enkaz altında kalanların sosyal medya aracılığılla yardım talep etmesi ve kurtarılması (Zincir ve Yazıcı, 2013), afet zararlarının azaltılmasında sosyal medyanın yönetişimi teşvik etmesi (Alexander, 2014), afetlerde sosyal medya kullanımının olumlu yanlarının olduğunu göstermektedir. Buna karşılık, sosyal medyanın insanlara veya itibarlarına zarar verme gibi kötü amaçlı kullanılması (URL 4), kötü niyetli söylentileri yayma, kişisel bilgilerin yetkisiz yayılması, mahremiyet ihlalleri, şiddetli protestoları kışkırtma ve terörist faaliyetleri düzenleme gibi girişimleri içerebilirken (Alexander, 2014), afet sonrası sosyal medya paylaşımları, kişilerin psikolojik olarak olumsuz etkilenmelerine de neden olabilir.

Bu çalışmada, afet ve acil durumlarda davranış kuralları, etik ve medya konularını içeren ulusal ve uluslararası metinler baz alınarak, 30 Ekim 2020 tarihli İzmir Seferihisar Depremi sonrası yapılan geleneksel ve sosyal medya paylaşımlarının yarattı̆̆ etik ikilemler değerlendirilmiştir. Çalıșmanın ikinci bölümünde, konuyla ilişkili kavramsal çerçeve ele alınmış ve ilgili kavramlar analiz edilmiştir. Üçüncü bölümde, afetlerde sosyal medya kullanımının olumlu ve olumsuz yanları ve afet ve acil durumlarda haber içerikleri ve paylaşımlarında dikkat edilmesi gereken etik ilkeler analiz edilerek, çalışma konusu için vaka çalışması olarak belirlenen İzmir Seferihisar Depremi sonrası yapılan sosyal medya paylaşımlarına değinilmiştir. Dördüncü bölümde, çalışmanın sonuç ve öneriler kısmı yer almaktadır.

\section{KAVRAMSAL ÇERÇEVE}

\subsection{Afetler ve İletişim}

Afet, etkilenen toplumun veya topluluğun kendi imkânlarıyla baş edebilme yeteneğini aşan ve geniş çapta can, mal, ekonomik ve çevresel kayıplara neden olarak normal yaşam işleyişinin ciddi şekilde bozulmasıdır (URL 5). Afet ve Acil Durum Yönetimi Başkanlığı'nın (AFAD), açıklamalı afet yönetimi terimler sözlüğünde ise afet, "toplumun tamamı veya belli kesimleri için fiziksel, ekonomik ve sosyal kayıplar doğuran, normal hayatı ve insan faaliyetlerini durduran veya kesintiye uğratan, etkilenen toplumun baş etme kapasitesinin yeterli olmadığı doğa, teknoloji veya insan kaynaklı olay" olarak tanımlanmaktadır (URL 6). Dünyanın farklı yerlerinde gün içerisinde insan yaşamını doğrudan etkileyen ya da etkilemeyen birçok doğa ve insan kaynaklı olay meydana gelmektedir. Afetler, insan yaşamını belirli düzeyde etkileyen olaylar içerisinde değerlendirilebilir. Kısaca bir olayın afet olarak nitelendirilebilmesi için, olayın insan yaşamı üzerinde fiziksel, ekonomik, sosyal, psikolojik ve yaşadığı çevre üzerinde etkisi veya etkilerinin olması gerekmektedir. Bu duruma örnek olarak, volkanik aktiviteler dünyanın belirli bölgelerinde, özellikle Pasifik Okyanusu'nu çevreleyen "Ateş Çemberi" olarak adlandırılan bir alanda meydana gelmektedir. Bu volkanik aktivitelerin çoğu zaman insan yerleşimlerinden uzak alanlarda meydana geldiği için jeofiziksel bir tehlike olarak sınıflandırılırken, Haziran 2018'de Guatemala'da meydana gelen Volcan de Fuego patlaması, çevresindeki yerleşim yerlerine volkanik kül ve proklastik akış meydana getirmiştir. Bu patlamada 425 kişinin hayatını kaybetmesi ve 1.7 milyon insanın etkilenmiş olmasından dolayı bir volkanik patlama afeti olarak sınıflandırılmıştır (URL 7). Dünyada meydana gelen bu doğa kaynaklı afetlerin yanı sıra teknolojik, sosyolojik, ekonomik, askeri değişimlerin etkisiyle farklı niteliklere sahip afetler meydana gelmekte, sayı ve şiddet bakımından artarak çeşitlenmektedir (Karaman, 2017). Ayrıca iklim değişiklerinin neticesinde meteorolojik afetler, kuraklık ve çölleşme gibi afetlerin giderek sık yaşanması, hızlı ve denetimsiz kentleşmenin artması, hızlı nüfus artışları insan kaynaklı afetleri çeşitlendirirken, doğa kaynaklı afetlerin olumsuz sonuçlarının artmasına katkıda bulunmaktadır.

Afetler dünyanın farklı yerlerinde, insanlar var olduğundan beri meydana gelmekte ve insanların yaşamlarını olumsuz şekilde etkilemektedir. Sismik aktiviteler, iklim değişiklikleri, hızlı nüfus artışı, teknolojik ilerlemeler, tüketimin artması, doğal kaynakların azalması gibi daha birçok 
faktörün gelecekte afetlerin meydana gelmesini ve olumsuz etkilerinin artmasını olasılıklı kılması, toplumların afetler konusunda hem yapısal hem de toplumsal olarak hazırlıklı olmalarını gerektirmektedir. Bu bağlamda, farklı boyutları ve özellikleri olan, günümüzde bütünleşik afet yönetimi olarak adlandırılan yönetim sistemi, sağlık, mühendislik, mimarlık, ekonomi, yönetim, işletme, sosyal, psikoloji, coğrafya gibi pek çok disiplini içinde barındırmaktadır (Karaman, 2017: 3). Afetlerin meydana gelmesiyle bozulan toplum düzeninin yeniden inşa edilmesi ve öncekinden daha iyi bir yaşamın sağlanabilmesi için, afet yönetiminde disiplinlerarası çalışma modeli önemli bir yer tutmaktadır.

İletişim, çeşitli yönleriyle ele alınan ve çok sayıda tanımı bulunan bir kavramdır. Genel olarak iletişim, insanların bireysel varlığını ve toplumsal ilişkilerini devam ettirebilmesi için toplumsallaşmanın ana unsuru olarak ele alınan yaşamsal ihtiyaçlardan biri olup, her etkileşim sürecinde iletişim söz konusudur (Toker, 2017). Afetler açısından bakıldığında, iletişim; afet planlama, müdahale ve iyileştirmenin (toparlanma) temel bir birleşenidir (Houston, et al., 2014). Afet iletişimi, hükümetler ve acil durum yönetim organizasyonları tarafından çoğunlukla geleneksel ve sosyal medya aracılı̆̆ıla halka yayılan afet bilgileri ile ilgilidir (Fraustino, et al., 2012). Sosyal medyanın ortaya çıkmasıyla birlikte, afet bilgilerinin paylaşımı ve haberlerinin yayılması konusunda bireylerin de yeni ve etkili bir paydaş haline geldiği söylenebilir. Afetlerin yaşanmasıyla, çoğunlukla iletişim ve bilgi alt yapısı zarar görmekte ve bunun sonucu olarak bilgi akışı yetersiz kalabilmektedir. Belirsizlik ve tehdit büyüdüğünde oluşan bu iletişim kapasitesindeki azalma, bilgi talebini arttırmaktadır (Houston, et al., 2014).

Afetlerin yaşanma sıklığının artmasıyla birlikte, hızlı müdahale için bilgi akışı daha önemli hale gelmektedir. Web ve internet teknolojileri olarak adlandırılan yeni iletişim araç ve ortamları, geleneksel medyaya kıyasla daha fazla iki yönlü iletişim fırsatı sunmaktadır. Ayrıca sadece bilgi iletmenin değil aynı zamanda örgütler tarafından bilgi üretme ve paylaşmanın bir aracı olarak kullanılan diğer iletişim araçlarından interaktif olması, kamuoyu ile etkileşim ve diyaloğa açık olması gibi özellikleriyle farklılıklara sahiptir (Akdağ ve Taşdemir, 2006:153).

\subsection{Sosyal Medya}

Sosyal medya (sosyal ağ veya Web 2.0 olarak ta adlandırılmaktadır), kullanıcılarının herkese açık veya kısmen açık olan profillerini ve içeriklerini geliştirmeleri ve diğer kullanıcıların profil ve içerikleriyle bağlantı kurmalarına olanak tanıyan, çeşitli web tabanlı platformlar ve hizmetler için kullanılan geniş bir terimdir (Boyd \& Ellison, 2008). Genel olarak sosyal medya, çeșitli ve farklı çevrimiçi iletişim araçlarını kapsayan geniş bir terimdir (Coombs, 2015). Sosyal medyanın ortaya çıkması, gelişmesi ve gün geçtikçe daha çok fonksiyon ile kullanıcılarına hizmet vermesine olanak tanıyan teknoloji "Web 2.0" teknolojisidir (Zincir ve Yazıcl, 2013). Web 2.0 teknolojisi, kullanıcılarına bilgi üretimi, bilgi paylaşımı, web sayfalarına video eklemeleri ve daha birçok özelliği kullanabilme imkânı sağlamaktadır (Postman, 2008). Sosyal medyaya erişim, genel olarak masaüstü veya dizüstü bilgisayarlar, akıllı telefonlar ve tabletler dahil çeşitli bilgi işlem aygıtlarıyla sağlanabilmektedir (Houston et al., 2014). Günümüzde sosyal medyaya erişim sağlayan bireylerin, ağırlıklı olarak akıllı telefon ve tabletler gibi mobil medya aygitlarını kullandıkları söylenebilir. Sosyal medya denildiğinde akla Facebook ya da Twitter gelmesine rağmen, sosyal medya; fotoğraf ve video paylaşım sitelerinden, derecelendirme ve inceleme forumlarına kadar çok sayıda web ve mobil tabanlı teknolojileri içermektedir (Fraustino et al., 2012). Tablo 1'de sosyal medya tipleri ve her biri için bazı örnekler verilmektedir. 
Tablo 1. Sosyal Medya Tipleri ve Örnekleri

\begin{tabular}{ll}
\hline Sosyal Medya Tipi & Örnekler \\
\hline Bloglar & Blogger, WordPress \\
Tartışma forumları & LiveJournal, PorBoards \\
Konum izleme ve görüntüleme & Banjo, Foursquare \\
Mikro-Bloglar & Tumblr, Twitter \\
Fotograf ve video paylaşımı & Flickr, Instagram, Pinterest, Vine, \\
Sosyal yer imi (imleme) & Youtube \\
Sosyal ticaret & Del. icio. us, Diigo \\
Sosyal keşif motorları ve haber & Groupon, Polyvore \\
kaynakları & Reddit, StumbleUpon \\
Sosyal müzik kaynakları & \\
Sosyal ya da profesyonel ağlar & Pandora, Spotify \\
Sosyal derecelendirme ve incelemeler & Facebook, Linkedln \\
Sosyal ișe alım & AngiesList, Yelp \\
Sosyal seyahat & Indeed, Glassdoor \\
Video ve metin sohbeti & TripAdvisor, Tripline \\
Wikis & $\begin{array}{l}\text { Google Hangouts, mobile texting, } \\
\text { Skypatsapp }\end{array}$ \\
\hline Kaynak: Fraustipedia, Wikispaces \\
\hline
\end{tabular}

(Kaynak: Fraustino, Liu and Jin, (2018) çalışmasından derlenmiştir.)

21. yüzyılda büyük kitleleri bir araya getiren sosyal medyanın, tüm dünyada gün geçtikçe kullanımının arttığı, ilgili alanda yapılan araştırmalarda görülmektedir. ABD merkezli Pew Research Center tarafından yapılan çalışmaya göre; Şubat 2005'te araştırma katılımcılarından sosyal ağ sitelerini kullananların \%8 olduğu, 2012 yılında bu oranın \%67’ye çıktığı ve 2013 yılında çevrimiçi Amerikalı yetişkinlerin yaklaşık üçte ikisinin (\%72) sosyal ağ sitelerini kullandıkları belirtilmiştir (URL 8). We are Social Ocak 2021 raporuna göre ise (URL 9), hem dünya genelinde hem de Türkiye özelinde web ve internet teknolojileri kullanıcılarının arttı̆̆ görülmektedir (Tablo 2 ve Tablo 3). Ayrıca rapora göre, küresel çapta 2016 yılında sosyal medya kullanıcı sayısı 2,31 milyar iken, 2017 yılında 2,79 milyar, 2018 yılında 3,2 milyar, 2019 yılında 3,46 milyar, 2020 yllında 3,71 milyar ve 2021 yılında 4,2 milyara ulaşmıştır.

Tablo 2' de, Ocak 2020 ve Ocak 2021 tarihlerinde yayınlanan dünya çapındaki bazı dijital veriler sunulmuştur. Buna göre, bir önceki yılın verileriyle kıyaslandığında, dünya çapında nüfus artışına paralel bir şekilde, mobil telefon kullanıcıları, internet kullanıcıları, aktif sosyal medya kullanıcılarının sayısında artış olduğu görülmektedir.

Tablo 3'te Ocak 2021 tarihinde yayınlanan Türkiye özelindeki bazı dijital veriler sunulmuştur. Buna göre, bir önceki yılın verileriyle kıyaslandığında, Türkiye'nin nüfus artışının yanı sıra, mobil telefon kullanıcı sayısı, internet kullanıcı sayısı, aktif sosyal medya kullanıcı sayısı, günlük internet kullanırken harcanan süre ve günlük sosyal medya kullanırken harcanan sürenin arttığı görülmektedir (URL 10). Tablo 2 ve Tablo 3'teki veriler kıyaslandığında, Türkiye'de mobil telefon 
kullanıcı sayısı (\%2.7), günlük internet kullanılırken harcanan süre (\%6.2) ve günlük sosyal medya kullanırken harcanan süredeki (\%3.5) artışların dünya çapındaki ortalamaların üzerinde olduğu görülmektedir. Diğer yandan Türkiye'de yıllık internet kullanıcı sayısındaki artışın (\%6.0) ve aktif sosyal medya kullanıcı sayısındaki artışın (\%11.1) dünya çapındaki ortalamadan daha az olduğu görülmektedir.

Tablo 2. Dünya Çapındaki Bazı Dijital Veriler

\begin{tabular}{lrrr}
\hline Dünya & Ocak 2021 & Ocak 2020 & $\begin{array}{r}\text { 2020 Yılına göre } \\
\text { Yüzdelik Artıș }\end{array}$ \\
\hline Nüfus & 7.83 milyar & 7.75 milyar & $\% 1.0$ \\
Mobil telefon kullanıcıları & 5.22 milyar & 5.19 milyar & $\% 1.8$ \\
İnternet kullanıcıları & 4.66 milyar & 4.54 milyar & $\% 7.3$ \\
Aktif sosyal medya kullanıcıları & 4.20 milyar & 3.80 milyar & $\% 13.2$ \\
$\begin{array}{l}\text { Günlük internet kullanırken } \\
\text { harcanan süre (Dünya }\end{array}$ & $\begin{array}{r}\text { 6 saat } 54 \\
\text { ortalaması) }\end{array}$ & dakika saat 43 dakika & $\% 4.0$ \\
$\begin{array}{l}\text { Günlük sosyal medya } \\
\text { kullanırken harcanan süre } \\
\text { (Dünya ortalaması) }\end{array}$ & 2 saat 25 & 2 saat 24 dakika & $\% 0.4$ \\
\hline (Kaynak: URL 2 ve URL 9'daki raporlardan derlenmiştir.) & & \\
\hline
\end{tabular}

Tablo 2. Ocak 2021 Türkiye’nin Bazı Dijital Verileri

\begin{tabular}{|c|c|c|}
\hline Türkiye & Ocak 2021 & $\begin{array}{l}2020 \text { yılına göre } \\
\text { Yüzdelik Artış (Kişi } \\
\text { sayısı) }\end{array}$ \\
\hline Nüfus & 84.69 milyon & \%1.0 (806 bin kişi) \\
\hline Mobil telefon kullanıcıları & 76.89 milyon & \%2.7 (2 milyon kişi) \\
\hline İnternet kullanıcıları & 65.80 milyon & \%6.0 (3.7 milyon kişi) \\
\hline Aktif sosyal medya kullanıcıları & 60.0 milyon & \% 11.1 (6.0 milyon kişi) \\
\hline $\begin{array}{l}\text { Günlük İnternet kullanırken } \\
\text { harcanan süre (16 ile } 64 \text { yaş } \\
\text { aralığında) }\end{array}$ & 7 saat 57 dakika & \%6.2 (7 saat 29 dakika) \\
\hline $\begin{array}{l}\text { Günlük sosyal medya kullanırken } \\
\text { harcanan süre }\end{array}$ & 2 saat 57 dakika & $\% 3.5$ (2 saat 51 dakika) \\
\hline
\end{tabular}

Sosyal medya kullanımının giderek artmasının yanı sıra, diğer iletişim araçlarının gelişimiyle kıyaslandığında oldukça hızlı bir gelişimin olduğu söylenebilir. Nitekim Orsburn farklı bir bakış açısıyla bunu göstermiştir. Orsburn’a göre;

- Sosyal medya web'deki 1 numaralı faaliyet haline gelmiştir.

- Radyonun 50 milyon kullanıcıya ulaşması 38 yıl almıştır.

- Televizyonun 50 milyon kullanıcıya ulaşması 13 yıl almıştır.

- İnternetin 50 milyon kullanıcıya ulaşması 4 yıl almıştır. 
- Sosyal medya platformu Facebook'un 100 milyon kullanıcıya ulaşması 9 ay almıştır (Orsburn, 2012).

Sosyal medya platformlarının giderek artan kullanıcı sayısı ile yaşamın normal akışında yeni insanlar ile bağlantı kurmak için önemli bir iletişim aracı haline geldiği söylenebilir. Afet ve acil durumlar gibi olağanüstü zamanlarda ise, sosyal medya platformları çok seslilik, dayanışma, bilginin kısa sürede çok fazla kişiye yayılması gibi olumlu gelişmelerin yanında hem kamu hukukunu hem de özel hukuku kapsayan çeşitli uyuşmazlıklar olabilmektedir (Çakır, 2017).

\subsection{Etik}

Etik, birçok düşünür, yazar ve bilim insanı tarafından tanımlanmış ve felsefenin en eski disiplinlerinden biri olarak kabul edilmektedir. Kelime kökeni olarak Eski Yunan'a dayanan ve karakter ve davranıș anlamına gelen "etos" sözcügünden türemiştir. Günlük kullanımda genellikle etik kavramı ve ahlak kavramı birbiri yerine kullanılmasına rağmen, hedef ve sonuç bakımından farklı kaygılara sahiptirler (Tenikler, 2012). Ahlak, bir toplumda yaşayan bireylerin, davranışlarına yol gösteren ve söz konusu toplum tarafından benimsenen temel değerler bütününü ifade ederken, bu davranış kurallarını sorgulama, savunma ve kritik etme çabaları etik kavramının alanına girmektedir (Tenikler, 2012). Etik, evrensel olarak kabul gören kurallardır.

Etik, "Ahlaki açıdan kabul edilen bireysel, kurumsal ve toplumsal değerlerin tanımlanması ve bu değerlerin insan davranışlarının değerlendirilmesinde temel ölçü olarak kullanılması şeklinde tanımlanabilir" (Seib ve Fitzpatrick 1997'den akt. Erol, 2009). Hali hazırda geleneksel medyadaki etik sorunlar devam ederken, sosyal medyanın insan yaşamının merkezinde yer almasıyla beraber, bu alanda da etik sorunlar gündeme gelmiștir (Öztürk, 2015). Sosyal medya kullanımının yaygınlaşmasıyla beraber, sözlü ve görsel olarak paylaşılan içerikler konusunda özel hayatın gizliliği, kişisel bilgilerin ihlali, "post truth" (gerçek dışı) haberler, nefret söylemleri, yanlış bilgi paylaşımı gibi daha pek çok etik sorunlar tartışılmaya başlanmıştır.

Etik, afet ve acil durum iletişiminde hayati bir husustur. Bilginin hızla ve güvenli bir şekilde yayılmasının afet ve acil durumlarda daha az zararla atlatılmasındaki kilit rolüne karşılık, günümüzde toplumun büyük bir bölümü tarafından kullanılan sosyal medya platformları vasıtasıyla bilginin yanıltıcı, yanlış veya başka şekillerde zarar verici paylaşımları hem etkilenen toplum hem de karar vericiler için tehdit oluşturabilmektedir.

\section{AFETLER VE SOSYAL MEDYA KULLANIMI ARASINDAKİ İLIŞKİNIN ANALİŻ}

\subsection{Afetlerde Sosyal Medya Kullanımının Olumlu Yanları}

Afet ve acil durumların öncesi, sırası ve sonrasında bilgi paylaşımının sağlanabilmesinde hem geleneksel medya hem de sosyal medya önemli aktörler haline gelmiştir. Özellikle günümüz modern teknolojisi ve sosyal medya vasıtasıyla afetlerde iletișim için yeni firsatlar oluşmuştur (Kapur, Dyal \& Bezek, 2017). Küresel çapta sosyal medya kullanımının hızlı gelişimi ve yaygınlaşması; arama ve kurtarma faaliyetleri, uyarılar, yardım girişimleri, etkilenen insanların ve gönüllülerin mobilizasyonunun sağlanması, kaçış yolları için kriz haritaları ve bir afetin devamında etkilenen toplumun üyeleriyle bağlantı kurulması gibi acil durum bilgilerinin paylaşımı için (Qadir et al., 2016), sosyal medyanın önemi artmaktadır. Afet zararlarının azaltılmasında sosyal medya platformlarının afet öncesi, afet sırası ve afet sonrasında yapabilecekleri, rol ve sorumlulukları farklılık göstermektedir.

Afet öncesi dönemde temel amaç toplumu afetlere karşı hazırlamak ve direnç kazanmasını sağlamaktır (UNICEF, 2019). Bu amaçla yapılan bilgilendirme, bilinçlendirme, toplumu afete hazırlama faaliyetlerinde sosyal medya etkin bir şekilde kullanılabilmektedir (Dufty, 2012). Bireylerin ve toplumun afetlere karşı ne gibi hazırlıklar yapabileceği, toplumdaki kaynakların 
neler olduğu ve bunlara ulaşma yolları, toplanma ve barınma alanlarının bilgisi ve bu alanlara nasıl ulaşacakları, afet sonrasında sağlanan temel hizmetlerden nasıl faydalanabilecekleri gibi önemli bilgiler yine sosyal medya araçları ile herkesin erişimine açık ve hızlı bir şekilde halka ulaştırılabilmektedir (URL 11). Bu bilgiler ile beraber afet öncesi dönemde sosyal medya araçlarının, kurumlararası koordinasyonun sağlanması, kamu spotları, erişilebilir, çevrimiçi eğitim portalları ve tüm vatandaşların bilgilendirileceği ve gelişmelerden haberdar olabileceği hizmetlerin verilmesinde olumlu katkıları bulunmaktadır.

Afet sırasında, yaşanan kriz durumu ile ilgili halkın açık ve dürüst bir şekilde bilgilendirilmesi, toplumdaki kaynaklar hakkında gerekli yönlendirmenin yapılması, toparlanma sürecinde ihtiyaç duyulan desteğin hızlı bir şekilde sağlanabilmesi, kişi ve grupların iyilik hali bilgilerinin gerekli kişi ve kurumlarla paylaşılabilmesi aşamalarında sosyal medya araçları kullanışlı olabilecektir (Merchant, Elmer \& Lurie, 2011). Yaşanan afet tipine ve etki derecesine bağlı olarak, afetler gerçekleștiği bölgenin elektrik altyapısına zarar verebilmekte, ayrıca kullanım yoğunluğu nedeniyle iletişim ve haberleşme altyapılarında da çöküntüler yaşanabilmektedir. Bu gelişmelere karşı daha dirençli olan internet tabanlı uygulamaların önemi bir kez daha ortaya çıkmaktadır. $\mathrm{Bu}$ duruma örnek olarak, 26 Eylül 2019'da İstanbul'da meydana gelen 5.8 büyüklüğündeki deprem sonrası, ülkedeki 3 büyük GSM operatörlerinin kullanıcıları, mobil telefon ses iletişiminde yoğunluk nedeniyle bir süre kesintiler yaşamıștır. Mobil cihazlardaki bu kesintinin yaşanmasıyla, kişiler arası iletişim internet tabanlı çeşitli uygulamalar vasıtasıyla sağlanmıştır. Bu uygulamalar çoğunlukla sosyal medya platformları olmuştur. Benzer durumlar, 24 Ocak 2020 Elâzı ̆̆ Depremi ve 30 Ekim 2020 İzmir Seferihisar Depremi'nde de yaşanmış, gelişmeler üzerine AFAD, vatandaşları, haberleşmenin kesintisiz bir şekilde sürdürülebilmesi için SMS ve internet tabanlı uygulamaları kullanması yönünde uyarmıștır (URL 12; URL 13). Bu sebeple afet ve acil durum bölgesinde yaşayan bireylerin iletişim içerisinde kalabilmesi veya afet bölgesi dışından, afet bölgesi ile bağlantı kurmak isteyenlerin sosyal medya uygulamalarını kullanabilmesi oldukça önem arz etmektedir (Zincir ve Yazıcı, 2013). Sosyal medya uygulamalarının GPS teknolojisi ile yer bildirimi yapabilme özelliği afet ve acil durumlarda, afetten etkilenenlerin hayatlarının kurtarılmasına katkı sağlayabilmektedir (Crowe, 2011). 2011 Van Depreminde enkaz altında kalan bir vatandaşın Twitter uygulamasını kullanarak, o an ulusal bir kanalda canlı yayınlanmakta olan programa adres bilgilerini göndermesi ve bu bilgilerin arama kurtarma ekiplerine ulaştırılmasıyla, arama kurtarma ekipleri enkaz çalışmalarını gerçekleştirerek iki kişinin hayatını kurtarmışlardır (Zincir ve Yazıcı, 2013). ABD'de meydana gelen Sandy ve Harvey Kasırgaları, Japonya'daki deprem ve tsunami, İtalya ve Şili'deki depremler ve Avustralya'daki Queensland selleri gibi geçmişte meydana gelen afet ve acil durumlarda, sosyal medya hem afet ve acil durum yönetimi hem de afet yardımı için güçlü bir araç olarak hizmet etmiştir (Lovari \& Bowen, 2019).

Afet sonrası süreçte ise, afet yönetiminin temel amacı hayatı olabildiğince hızlı bir şekilde normale döndürmektir. Bu amaç doğrultusunda, halkın ve ilgili diğer sektörlerin yaşanan durumla ilgili belirli periyotlarla bilgilendirilmesi, tüm toplumun yaşanan süreçle ilgili toparlanma ve baş etme mekanizmalarının geliştirilmesi amacıyla ihtiyaç duyduğu bilgilerin ve kaynakların hızlı, güvenli ve erişilebilir biçimde paylaşılması ve ayrıca afet öncesi, sırası ve sonrasında yapılan tüm medya hizmetlerinin gözden geçirilmesi, yaşanacak bir sonraki afet için bireyler ve kurumların daha hazırlıklı olmasını sağlayacaktır (Merchant, Elmer \& Lurie, 2011). Sosyal medya platformları ile bilginin saniyeler içinde geniş kitlelere yayılması sayesinde, herhangi bir bölgede yaşanan kriz ile ilgili, toplum çok kısa sürede bilgi sahibi olabilmekte, platformlar aracılığıyla toplumsal bir güç birliği ve dayanışma sağlanabilmektedir. Bu güç birliği ve dayanışma, yardım toplanması, yardımların yönlendirilmesi, ihtiyaç sahibi kişilerin duyurulması, ilgili kurumların haberdar edilmesi yolları ile insani yardım operasyonlarına entegre edilebilmektedir. Kriz bölgesinden gelen bir fotoğraf karar vericilerin veya afet ve acil durum kuruluşlarının dikkatini çekebilmekte ve gerekli müdahale gücünün bölgeye yönlendirilmesini sağlayabilmektedir. Sosyal medya uygulamalarının kullanıcı kitlesinin genişliği hem kurum ve kuruluşlara hem de vatandaşların kullanımına açık olması, uygulamaların, bölgede yürütülen faaliyetlerin ve önemli bilgilerin kritik 
kişi ve kuruluşlara ulaşması anlamında yüksek potansiyele sahip olmasını beraberinde getirmektedir. Sosyal medyanın asıl gücünün arkasında kullanıcı kitlesinin genişliği ve sınırlarının diğer platformlara nazaran daha esnek olmasıdır. Bu özgürlük alanı bazı durumlarda oldukça işlevsel sonuçlar elde edilmesini sağlarken, bir sonraki bölümde değinildiği gibi hukuk ihlalleri ve etik problemlerin yaşanması gibi olumsuz sonuçlar da doğurabilmektedir (Çakır, 2017). Bu bağlamda, sonraki bölümde afetlerde sosyal medya kullanımının olumsuz yanlarına değinilmiştir.

\subsection{Afetlerde Sosyal Medya Kullanımının Olumsuz Yanları}

Afetlerin ortaya çıkardığı başta can ve mal kayıpları olmak üzere, fiziksel ve ruhsal hasarların sadece afeti doğrudan yaşayanlarda değil, afetten doğrudan etkilenenlerin aileleri ve yakınlarında, afet ve acil durum çalışanlarında ve afeti sadece medyadan takip edenlerde de görülebildiği bilgisi; afet, acil durum ve kriz ortamlarında medyanın payının ne kadar büyük olduğunun göstergesidir (URL 14). Bütünleşik afet yönetim sisteminin çok büyük bir bileşeni olan medyanın kapsamının oldukça genişlemesi, ulaşılabilir olması, bilgiyi çok kısa sürede yayabilmesi gibi özellikleri, bilhassa kriz durumlarında kontrolü oldukça güçleştirebilmektedir.

Hem geleneksel hem sosyal medyanın afet ve acil durumlarda sıklıkla karşılaşılan ilk dezavantajı, afet bölgesinde yaşanan travmatik hikâye ve görüntülerin tüm toplum ile rahatlıkla, herhangi bir süzgeçten geçmeden, toplumda yaratacağı etkiler düşünülmeden paylaşıma açılmasıdır. $\mathrm{Bu}$ görüntüler ile afeti doğrudan yaşamayan kişiler dahi psikolojik sorunlar ile karşı karşıya kalabilmekte ve rutin hayat akışının dışına çıkabilmektedir (URL 15). Geçmişte yaşanmış afetlerde karşılaşılan bu durum, sosyal medya platformlarının da devreye girmesiyle daha ciddi bir sorun haline gelmiştir. Özellikle görüntü içeriklerinde dezavantajlı grupların dramatizasyon tekniği ile ele alınarak, yaşadığı travmatik hikâyenin en çıplak haliyle yansıtılması, sadece afetin yaşandığı bölgenin değil, toplum genelinin psikolojisini de olumsuz etkileyebilmektedir. 23 Ekim 2011 Van depremi ve 30 Ekim 2020 İzmir Seferihisar depreminin enkaz görüntülerine hala tüm medya platformlarında rahatlıkla ulaşılabilmektedir. Ayrıca 1992 yılında afet ve acil durumlarda müdahalelerin kolaylaştırılmasını amaçlayan birçok insani yardım kuruluşundan teşkil edilmiş olan Kuruluşlararası Daimî Komitesi'nin (IASC); insanların çektiği acılara ilişkin sansasyon yaratacak görüntülerin yayınlanmaması (URL 15), yine Uluslararası Kızılhaç ve Kızılay Hareketi'nin (ICRC), afetten etkilenenlerin umutsuz ve çaresiz objeler olarak tüm topluma yansıtılmamasına ilişkin yaklaşımları (URL 16), söz konusu görüntülerin paylaşılmasını, tartışılması gereken konular haline getirmiștir. Özellikle afet ve acil durumların hemen sonrasında yürütülen kurtarma çalışmalarında ve yardım dağıtımlarında sıkça karşılaşılan bu görüntüler, kişileri mağdur, biçare ve umutsuz göstererek, hak odaklı olarak sürdürülmesi gereken müdahale çalışmalarının kapsamının değișmesine yol açabilmektedir. Bu nedenle, afet ve acil durum ile ilgili tüm kurum ve kuruluşların afet öncesi, sırası ve sonrasında yapacakları çalışmaları, onurlu yaşam hakkı çerçevesinde yürütmeleri gerekmektedir.

Afet ve acil durumlarda kritik konulardan bir tanesi de bilgi yönetimi konusudur. Başta afetten etkilenen bölgenin, sonrasında tüm toplumun doğru ve açı bilgiye ulaşabilmesi, toplumun ruh sağlığının toparlanmasında belirleyici bir etken iken, güven duygusunun yeniden inşasında ve toplumun toparlanmasında önemli bir yere sahiptir (UNICEF, 2019). Bu sebeple; afet görüntülerinin, yanlış veya kaynağ doğrulanmayan bilgilerin toplumda bırakacağ etkiler düşünülmeden yapılan habercilik anlayışı veya paylaşımlar, halihazırda afetten zarar görmüş afet bölgesinde yaşayanlar olmak üzere tüm toplumun toparlanmasını geciktirebileceği gibi, daha kaotik durumların yaşanmasına da sebep olabilecektir. Afetlerden sonra afetin nedenleri, etkileri, kaç kişinin etkilendiği ve gelecekte olması muhtemel afetlerin ne zaman ve nerede olacağına yönelik yayınların bilimsel gerçeklikten uzak bir biçimde yapılması bu konuya örnek olarak gösterilebilir.

Sosyal medya araçları sayesinde toplumdaki çoğu bireyin kendine ait bir medya alanının olması ile birlikte, afet dönemlerinde üretilen haber içeriklerinden sorumluluk, sadece medya sektörü 
çalışanları ile sınırlı kalmamakta, mobil telefonu olan ve sosyal medya araçlarıyla yaşanan olayla ilgili içerik üreten herkes bu sorumluluğun bir parçası haline gelmektedir. Yaşanan afet ile ilgili bilgi almak isteyen vatandaş ve çalışanların yardım çalışmalarını aksatacak şekilde sıcak bölgeye girme çabası, zaman zaman yardım çalışmalarının aksamasına sebep olabilmektedir (UNICEF, 2019). Afet sonrası saniyelerin bile hayat kurtarma anlamında çok önemli olduğu aramakurtarma çalışmalarında, halkta dahil tüm afet bileşenlerinin yardım çalışmalarını aksatmamak adına gereken özeni maksimum derecede göstermesi gerekmektedir. Bu durum, çalışmalar ile ilgili bilgi verilmemesi anlamına gelmemektedir. Aksine ilgili kurum ve kuruluşların belirli aralıklarla, çalışmalar ve yürütülen faaliyetlerle ilgili bilgilendirilmesi ve güvenli alan uygulamaları, bu tarz durumların oluşmasını engelleyebilecektir.

Afet durumlarında sosyal medya hesaplarından yapılan paylaşımlarda konunun hukuksal boyutu da değerlendirilmelidir. Türkiye Cumhuriyeti Anayasası 20. maddesinde "Özel Hayatın Gizliliği" ve Türk Ceza Kanunu'nun (TCK) 134. maddesinde ise "Özel Hayatın Gizliliğini İhlal Suçu” konuları düzenlenmiştir. Özel hayat alanı, kişinin üzerinde tasarruf hakkının olduğu, diğerleri tarafından bilinmesini istemediği, hukuk tarafından gizliliği ve korunması kişilik hakkı olarak kabul edilen alanı tanımlamaktadır. Bu alanın yayın konusu yapılması kişilik haklarına saldırı niteliğindedir. Kişinin fotoğraf ve görüntülerinin, özel hayatının ayrılmaz birer parçası olarak düşünüldügünde, rızası dışında ve 1982 Anayasasının 20, 21 ve 22. maddelerinde belirtilen sınırlamalar dışında, medya platformlarında resim, ses ve video paylaşılması, TCK 134. maddesi kapsamında özel hayatın gizliliğini ihlal suçu niteliğinde değerlendirilebilmektedir (Türkel, 2010). Kişilik hakları ile benzer nitelikte 6698 Sayılı Kişisel Verilerin Korunması Kanunu konu ile alakalı bir diğer değinilmesi gereken düzenlemedir. Söz konusu kanunun 5. maddesine göre, kişisel veriler ilgili kişinin açık rızası olmaksızın işlenmemelidir. Kişisel verilerin işlenmesi ile ilgili istisnalar ise, verilerin milli güvenlik, kamu güvenliği, özel hayatın gizliliği ve kişilik haklarını ihlal etmemek kaydıyla sanat, tarih, edebiyat veya bilimsel amaçlarla kullanılmasıdır. Kişilerin bir afeti deneyimlemelerinden sonra görüntülerinin rızası dışında paylaşıma açılıp, ifşa edilmesi bu duruma örnek olarak gösterilebilir. Afet sonrası sosyal medya platformlarında yayılan bu görüntülerde, en başta kişinin rıza durumu, sonrasında kişinin müsait olup olmaması, bu görüntülerin, afet sonrasında onda ve toplumun diğer kalanında bırakacağı etki gibi konular önemsizleşmektedir. Sonuç olarak, söz konusu içerik özel hayatın gizliliğini ihlal etsin veya etmesin, kişinin görünmek istemeyeceği kötü bir durumda sağlanmış içeriğe sahip olabileceği ve kişinin yaşadığı afet sonrasında bu görüntülerle baş başa kalacağı unutulmamalıdır. Özel hayatın gizliliğinin ihlali suçuna benzer nitelikte, kişinin konuşmaları, görüntüsü, videosu vb.nin rızası dışında alınıp ifşa edilmesi suç niteliği taşıyabilmektedir. Kişilik hakkı ihlal edilen kişi bu durumda Medeni Kanun'un 23,24,25. maddeleri ve Borçlar Kanunu'nun 58. maddesine başvurarak hak arama yoluna gidebilmektedir (Çakır, 2017). Bu sebeple, afet öncesi, sırası, sonrasında veya insani yardım operasyonlarında kişilerin özel hayat gizliliğini ihlal eden, kişilik haklarına aykırı bir biçimde, onların rızası ve bilgisi dışında yayınlanan belgeler ile ilgili içeriği üreten kişinin sorumluluğu bulunmaktadır.

"Unutulma Hakkl" afet ve acil durumlarda geleneksel medya ve sosyal medya içeriklerinde tartışılan başka bir konudur. Medya paylaşımları, ilgili kişilerin, gizledikleri veya diğer kişilerce bilinmesini istemedikleri bilgi ve deneyimlerini geçmişte bırakmalarını ya da geleceklerinin etkilenmemesine yönelik beklentilerini daha da zorlaştırabilmektedir. Bu sebeple gündeme gelen "Unutulma Hakkı" ile internet ortamında, sosyal medya platformlarında veya dijital ortamda yer alan, kişiye ait rahatsız edici içeriğin, kişinin isteği üzerine ortadan kaldırılması olarak ifade edilmektedir. Teknoloji ve internetin bu denli gelişmesi bir yandan bu hakkın ortaya çıkmasına zemin hazırlarken, diğer yandan bu hakkın kullanımına veya hedeflenen mahremiyeti sağlayıp sağlayamayacağı konusundaki endișeleri de beraberinde getirmektedir. Bunun nedeni; internet ortamına giren bir içeriğin, hiç olmamış gibi silinip silinemeyeceği konusunun belirsiz olması, içeriğin dijital hafızaya bir kere yüklendiğinde, geri almanın mümkün gözükmemesi, içeriğin ana kaynaktan değil, arama motorlarının içeriğe ulaşacak yolları kapatması gibi uygulamalar 
olabilmektedir (Nalbantoğlu, 2018). Bu kapsamda, afet ve acil durumlarda medya içeriklerinde sıkça karşılaşılan etkilenen insan görüntüleri, bilinmesini istemediği, yaşadığı afet sonrasında, hatırlamak veya bu şekilde hatırlanmak istemediği, bireyin gelecekteki psikolojik iyilik halini etkileyebileceği sebeplerinden ötürü unutulma hakkı kapsamında değerlendirilebilmektedir.

Gerçekliğin önemini yitirmesi anlamında kullanılan "Post Truth" kavramı, bu bölümde değinilmesi gereken önemli bir kavramdır. Karar alma süreçlerinde mantığın, duyguların gerisinde kalması ve sonrasında kararların meşru bir zemine oturtulması amacıyla kullanılması (Baltaş, 2015), post truth kavramının önemini ortaya çıkarmaktadır. Oxford sözlügünde post truth kavramı, "duyguların ve kişisel kanaatlerin belirli bir konu üzerinde kamuoyunu belirlemede rasyonel gerçeklerden daha fazla etkili olması" olarak tanımlanmaktadır. Medya konusunda ise bu kavram "gerçek dışı haber" olarak tanımlanabilmektedir. "Post truth" haberler bilgi temeline dayanmayan, nefret söylemleri içeren ve çıkış noktası belli olmayan iddialardan türeyen haberlerdir. Sosyal medya araçlarında "post truth" haberlerin çok daha kolay üretilmesi, yayınlanması ve yayılması, doğru haberlere kıyasla sansasyonel ve gerçek dişı haberlerin daha çok ilgi görmesi ve yaşam şartları sebebiyle medya içeriklerini derinlemesine incelenme vaktinin olmaması, insan yaşamına entegrasyonunu kolaylaştırmıștır (Sarıoğlu, 2020). Afet ve acil durumlarda sosyal medya platformlarında, yaşanan afetle ilgili yanlış bilgilerin yayılması, gelecek afetlerle ilgili kehanetlerde bulunulması, yardım çalışmaları ile ilgili herhangi bir kaynağı olmayan haberler, gerçek dışı afet, enkaz, afetzede fotoğraf ve videoları gibi "post truth" haberler ile toplum algısı, tutum ve davranışları yanlış bir biçimde yönlendirilebilmekte, mantığın devre dışı bırakılıp duyguların ön planda olduğu, kontrolü zor bir ortam yaratılabilmektedir.

Afetlerde medya içeriklerinde sık karşılaşılan görüntülerden biri de objesinin dezavantajlı grupların olduğu içeriklerdir. Söz konusu dezavantajlı gruplar içerisinde ise çocukların özel bir yeri bulunmaktadır. Çocukların çoğu kültürde ortak değer olması ve medya için iyi bir içerik oluşturması bunun nedenleri arasında gösterilebilmektedir. Çocuk Haklarına Dair Sözleşmeye göre, erken yaşta reşit olma durumu hariç 18 yaşından küçük her birey çocuk olarak tanımlanmaktadır (URL 17). Afetlerde tüm medya araçlarında çocukların nasıl temsil edildiğine daha net bir açıklama getirebilmek için, öncelikle normal zamanlarda çocukların medyada nasıl temsil edildiğini incelemek gerekmektedir. UNICEF'in Çocuk Hakları ve Gazetecilik Uygulamaları Hak Temelli Perspektifine göre, çocuklar medya yayınlarında yetişkinlerle aynı oranda yer almamakta, yer aldığında ise ya şiddete maruz kalan kurbanlar ya da şiddetin kaynağı olarak kullanılmaktadır. Reyting aracı olarak kendilerine yer verilen çocuklar, sokakta yaşamayı tercih eden, suç üretmeyi seçen veya suçu işleyen, saldırgan bir dille itham edilen, daha çok eylemlerinin sonucuyla ilgilenilip nedenlerinin göz ardı edildiği bir şekilde kendilerine medyada yer bulabilmektedir (URL 18). Uluslararası Gazeteciler Federasyonu (IFJ)'na göre ise; çocuklar, medyada çaresiz kurbanlar olarak gösterilen, sansasyonel haber içeriklerine konu olan, özel hayatlarının gizliliğine dikkat edilmeyen, kalıp yargıların kullanıldığı haberlere konu olabilmektedir (URL 19). Ayrıca çocukların erken yaşta cinsel obje olarak yansıtıldığı, zaman zaman yetişkinler gibi davrandırıldığı, özetle çocukluklarının yok sayıldığı yayınlara da rastlamak mümkündür (URL 18). Afet durumlarında çocukların medyada nasıl temsil edildiği konusu ise diğer zamanlarda çocukların medyada nasıl temsil edildiği konusundan bağımsız hareket etmemektedir. Bu tarz durumlarda genellikle çocuklar, yaşanan krizden etkilenmiș, kurtarılmış ya da kurtarılamamış, yardım organizasyonlarında yardımı kabul eden pasif, mağdur kurbanlar olarak yansıtılan, etik kuralların zaman zaman göz ardı edildiği haber içeriklerinde kullanılabilmektedir. $\mathrm{Bu}$ konuya verilebilecek ve etik açıdan hala tartışmalara sebep olan temsillere örnek olarak, cansız bedeni Bodrum kıyılarında bulunan Aylan Kurdi' nin, Vietnam Savaşında saldırılardan kaçan kız çocuğunun, Sudan'da bir akbabanın yanında hayatını kaybetmek üzere olan çocuğun, 2011 Van depreminde moral vermek amacıyla yüzlerine yaşanan depremin büyüklüğüne atfen 7.2 yazılan çocukların, yine Van depremi ile birlikte 2020 Elâzığ ve İzmir Seferihisar depremlerinde enkaz içinden çıkarılan çocuk görüntüleri verilebilir. Kamu yararı ve çocuğun yüksek yararı kavramları arasındaki tercihlerin etik açıdan tartışmalara neden 
olduğu afet ve acil durumlarda çocukların medyada temsili, davranış kuralları ve etik konusu ulusal ve uluslararası kılavuzlar üzerinden bir sonraki başlıkta değerlendirilmiştir.

\subsection{Afet ve Acil Durumlarda Haber İçerikleri ve Paylaşımlarında Dikkat Edilmesi Gereken Etik İlkeler}

Çoğu alanda var olan ve çalışılan alana ilişkin bir çerçeve çizen, faaliyetlerde standart uygulamalara ulaşmayı hedefleyen etik ilkeler, gazetecilik ve medya alanlarında da mevcuttur. $\mathrm{Bu}$ başlık altında ilk olarak afet ve acil durumlarda kuruluşların dikkat etmesi gereken etik ilkelere yer verilmiş, sonrasında medya sektörü içinde çeşitli kurum ve kuruluşların habercilik faaliyetleri için geliştirdikleri etik ilkeler ortaya konmuş, son kısımda ise bu kuruluşların öncelikli grup olarak değerlendirdiği çocuk haberciliği ile ilgili kurallara yer verilmiştir.

Çeşitli kurum ve kuruluşların afetlerde, acil durumlarda, çatışma veya kriz ortamlarında, yardım çalışanlarının dikkat etmesi gereken etik ilkeleri ve davranıș kuralları çalıșmaları mevcuttur. Bu çalışmalardan ilki 1994 yılında Uluslararası Kızılhaç ve Kızılay Hareketi (ICRC) tarafından insani yardım alanında faaliyet gösteren kuruluşlara yönelik geliştirilen davranış kurallarıdır. Söz konusu ilkelerden biri, afet durumlarında medya yönetimi veya içeriği konusunda değerlendirilebilecek, insani zaruriyetin öncelikli olması ve hiçbir amacın, insan acısını azaltma amacından daha önemli olmadığı; son ilke ise, yardım kuruluşlarının bilgilendirme, tanıtım ve reklam çalışmalarında afetten etkilenen insanları umutsuz kurbanlar olarak değil onurlu bireyler olarak göstermesi gerektiğine yöneliktir (URL 16).

Kuruluşlararası Daimî Komitesi (IASC), Afet ve Acil Durumlara Yönelik Ruh Sağlığı ve Psikososyal Destek Kılavuzu'nda "zarar vermeme" ilkesine yer vererek, kuruluşların afetlerde yapacakları çalışmalarla, mevcut zarar görmüş nüfusa, daha da fazla zarar vermemesi gerektiğini belirtmektedir (URL 15). Söz konusu ilkeye, insani yardımda kalite ve hesap verilebilirlik konularını gündeme getiren, afetten etkilenenlere yönelik yapılan faaliyetlerin asgari standartlarını belirlemeyi amaçlayan Sphere Projesi'nde de değinilmiştir (URL 20). Afetlerde faaliyet yürüten insani yardım kuruluşlarının üzerinde uzlaştıkları temel nokta, insan onurudur. Yapılacak tüm faaliyetlerde bireylerin itibarının korunması ve onurlu bir yaşam sürme hakkı olduğu belirtilmektedir. Bireylerin onurunu zedeleyen, küçük düşüren veya bu şekilde hissetmesine sebep olan tüm davranış ve faaliyetlerden kaçınılması gerektiği üzerinde durulmaktadır (URL 21). Afetlerde davranış kuralları ve etik ilkeler üzerine çalışma yürüten kuruluşların odaklandığı diğer konular; eşitlik, bağımsızlık, ayrımcılık yapmama, toplum katılımı, yerel kapasitenin desteklenmesi, kültüre ve geleneğe saygı gösterilmesi gibi ilkelerdir.

Medya sektörü için geliştirilen etik ilkeler, ikilem yaratan durumlarda veya karşılaşılan zor durumlarda karar almaya kllavuzluk etmesi için geliştirilen kurallar bütünüdür. Daha çok geleneksel medya araçları için geliştirilen etik ilkeler ve davranış kuralları, medya sektörünün sınırlarının genişlemesiyle kapsamının değişmesine ihtiyaç duymaktadır. Medya sektörü ile ilgili etik ilkeler ve davranış kuralları ile ilgili evrensel olarak kabul edilmiş bir oluşum bulunmamakla beraber, bölgesel, ulusal ve kurumsal ilkeler bulunabilmektedir. Söz konusu bu ilkeler ise genelde; doğruluk, dürüstlük, nesnellik, tarafsızlık, hakkaniyet gibi bazı ortak değerlerin benimsendiği görülebilmektedir (URL 18). Medya konusunda geliștirilen etik ilkelere gelindiğinde konu ile ilgili Uluslararası Gazeteciler Federasyonu (IFJ)'nun “Gazetecilik Davranışlarına Dair İlkeler Beyannamesi”nin olduğu görülmektedir. Gazetecilerin mesleki tutumlarının standartlarını belirleyen deklarasyon, doğru bilgi ve halkın doğru bilgilere ulaşabilmesi, temel bilgilerin saklanmaması, haber içeriklerinin toplanmasında dürüst yöntemler kullanılması, mesleki gizliliğe dikkat edilmesi, her türlü ayrımcılıktan kaçınılması, ciddi mesleki hatalar olan haber çalma, yanlış ve art niyetli açıklamalar, onur kırıcı iftira niteliğinde açıklamalar ve rüşvet konularına odaklanmıştır (URL 22). 
Türkiye Gazeteciler Cemiyeti'nin (TGC) Hak ve Sorumluluk Bildirgesi, medya konusunda gazetecilerin doğru davranış kurallarını ortaya koymuştur. Söz konusu bildirgede ilk olarak; bireylerin görüntüleri, şayet kamusal kimliği yoksa ve kamuya açık bir alanda gerçekleștirilen faaliyetler dışında, kamu yararı olmadıkça izinsiz çekilmemeli ve kullanılmamalıdır. Ayrıca gazetecilerin haber içeriklerinde yönlendirme, yanıltma, zan altında bırakma, gerçeği çarpıtma gibi eylemlerden kaçınması gerektiği ifade edilmiştir. Bildirgede "Unutulma Hakkı" na da değinilmiş ve bireylerin bu hakkı kullanması durumunda, taleplerinin dikkatli bir șekilde incelenmesi gerektiği ifade edilmiştir. Sektörün, insanların damgalanmasına zemin hazırlamaması, bireylerin özel hayatlarını ilgilendiren içeriklerin kullanılmaması gerektiği konusu vurgulanmıştır. Bildirgede kamu yararı kavramı öne çıkarılmış ve görüntü, ses ve kayıtların, sahibinin rızası dışında ancak belirgin bir kamu yararı olduğu durumlarda kullanabileceği belirtilmiştir. Son olarak, şok halinde insanlar söz konusu olduğunda, meslek elemanının insani olması ve gizliliğe önem vererek duygu sömürüsünden kaçınması gerektiği belirtilmiştir (URL 23).

Afetlerde daha fazla üzerinde durulması gereken ve yardım faaliyetlerinde önceliklendirilen çocuklar konusunda ise medya sektörünün ekstra düzenlemeler yaptığı görülmektedir. Örnek olarak IFJ, UNICEF, Çocuk Hakları Bilgi Ağı (CRIN), TGC, British Broadcasting Corporation (BBC) gibi kuruluşların medyada çocuk söz konusu olduğunda özel prensipler geliştirdikleri görülmektedir.

TGC Medya ve Çeşitlilik Kılavuzu' nda medya kuruluşlarının tüm eylemlerinde Çocuk Hakları Sözleşmesini göz önünde bulundurması gerektiği, haber içeriklerinin çocuklar üzerinde yaratacağı etkinin değerlendirilmesi gerektiği belirtilmiştir. Medya çalışanlarının haber içeriğinin üretim sürecinde, çocuk söz konusu olduğunda en yüksek mükemmellik standardına ulaşılması, çocuklara zarar verecek içeriklerin engellenmesi, çocuğun ve velisinin rızasının olması ve mahremiyetine saygı duyulması, görüntü alınması gerekli olduğu hallerde dürüst yöntemler kullanılması, ayrımcılık yapılmaması ve onurlarının korunması, kalıp yargıların kullanılmaması, şiddetin asla meşru gösterilmemesi kurallarına uyması gerektiği belirtilmiştir (URL 24).

CRIN ise; çocuğu riske atacak herhangi bir içeriğin paylaşılmaması, hiçbir çocuğa zarar verilmemesi, travmatik anısını canlandıracak muamelelerden kaçınılması, çocuklar arasında ayrımcılık yapılmaması, sansasyonel sunumlar gerçekleştirilmemesi, çocuk ve velisinden izin alınması, çocuğun risk altında olup olmadığı konusunda kesin bir kanaatin olmadığı durumlarda, haber değeri yüksek olsa da tek bir çocukla ilgili değil, genel olarak çocukların durumlarıyla ilgili bir yöntem kullanılması gerekliliklerinden bahsedilmiştir.

IFJ'nin Çocuk Haberciliğiyle İlgili Rehber İlkeleri'nde; çocuk haberlerinde doğruluk ve hassasiyet açısından mükemmelin hedeflenmesi, çocuklara zararlı görüntülerin, çocuk medyası alanına girmemesi, sansasyonel sunum ve kalıp yargıların kullanılmaması, haber sonuçlarının değerlendirilmesi, çocuklara verilebilecek zararın en aza indirilmesi, bariz kamu yararı olmadığı sürece çocuğun kimliğinin gizlenmesi, çocuk görüntülerinin alınması aşamasında dürüst yöntemlerin kullanılması ve çocuğun kendisinin ve velisinin izninin alınması gereklilikleri ifade edilmektedir (URL 19).

BBC'nin Çocuklara İlişkin Yayıncılık İlkelerinde; çocukların fiziksel ve ruhsal iyilik hallerinin korunması, gereksiz duygu karmaşasına sokulmaması, rızalarının alınması, haberin sonuçlarından açık bir şekilde haberdar edilmesi gereklilikleri üzerinde durulmuştur.

UNICEF ise her çocuğun onurlu bir yaşam sürme hakkı olduğunu, özel hayatlarına saygı gösterilmesi gerektiği, kendisini ifade hakkı olduğu, çocuğun yüksek yararının her koşulda korunması ve savunulması gerektiği, onları riske atacak herhangi bir içeriğin kullanılmaması, hiçbir koşulda çocuklara zarar verilmemesi, çocuklar arasında ayrımcllık yapılmaması, tüm 
fotoğraflar, resimler, sesler ve kayıtlar için çocuktan ve velisinden izin alınması ve damgalanmaması gereklilikleri üzerinde durulmuştur (URL 25).

Görüldüğü üzere medya sektöründe veya çocuk alanında görev yapan kuruluşların çocuk haberleri ile ilgili üzerinde uzlaşılmış net bir standart etik ilkeler metni bulunmamasına rağmen, her bir kuruluşun çocuk haberciliği ile ilgili çizdiği çerçeve benzerdir. IFJ, BBC, UNICEF, CRIN ve TGC kılavuzlarında çocuk söz konusu olduğunda dikkat edilmesi gereken ortak kavramlar, onurlu yaşam, mahremiyetin korunması, özel hayatın ihlal edilmemesi, çocuğa hiçbir koşulda zarar verilmemesi, çocuğun yüksek yararı, hiçbir koşulda riske atılmaması, içerikler için çocuğun kendisinden ve sorumlusundan izin alınması, haberin doğuracağı sonuçların önceden değerlendirilmesi, kalıp yargıların kullanılmaması, sansasyonel sunumlardan kaçınılmasıdır. $\mathrm{Bu}$ bağlamda, sonraki bölümde ulusal ve uluslararası metinler ve değinilen ortak değerler üzerinden 30 Ekim 2020 Seferihisar depremi değerlendirilmiştir.

\subsection{Araştırmanın Amacı ve Yöntemi}

Afetlerle ilgili literatür incelendiğinde, Türkiye'de farklı afet türlerinin yaşanabildiği görülmektedir. Bu afet türlerinden yaşanma sıklığı ve yarattığı kayıplar bakımından depremlerin özel bir konumu bulunmaktadır. Nitekim, ülke nüfusunun büyük bir çoğunluğunun yaşadığı yerleşim yerlerinin deprem tehlikesi altında olması, afet yönetim politikaları içerisinde deprem afetinin öncelikli olarak yer almasını gerektirmiştir. Ege bölgesi depremsellik bakımından dünyanın en aktif bölgelerinden birinde yer almaktadır. Çalışma kapsamında değerlendirilen İzmir ili depremsellik bakımından, Büyük Menderes ve Gediz grabenleri neotektonik rejim içerisinde Batı Anadolu'nun gelişen en büyük tektonik yapıları içerisinde yer almaktadır. Son yüzyıl içinde, 1928 yılında 6.5 büyüklüğünde Torbalı ilçesinde, 1992 yılında 6.0 büyüklüğünde İzmir'in güneyinde, 2003 ve 2005 ylllarında 5.7 büyüklüklerinde Urla ilçesinde, 2017 yılında 6.2 büyüklüğünde Karaburun ilçesinde ve 2020 yılında 6.6 büyüklüğünde Seferihisar açıkları ile Sisam (Samos) Adası arasında depremler meydana gelmiştir (URL 26).

Türkiye'de son yıllarda yıkıcı etkileri olan depremlerden biri olmasından dolayı çalışma da 30 Ekim 2020 tarihli İzmir Seferihisar depremi değerlendirilmiştir. Ayrıca, afetlerde sosyal medya kullanımı üzerine çeşitli çalışmalar olmasına rağmen, konu ile ilgili sosyal medya kullanımının yaratacağı etik ihlaller konusunda çalışmaların kısıtlı olması nedeniyle, örnek olay olarak İzmir Seferihisar depreminin değerlendirilmesi amaçlanmıştır.

Çalışma kapsamında afetlerde medya ve etik konularıyla ilgili literatür taraması yapılmıştır. $\mathrm{Bu}$ kapsamda, ICRC, IASC, IFJ, TGC, CRIN, BBC, UNICEF ve Sphere Projesi metinlerinde yer alan ilkeler baz alınarak, İzmir Seferihisar depremi sonrasında, arama kurtarma çalışmalarının yürütüldüğü 30 Ekim ile 4 Kasım 2020 tarihleri arasında yapılan sosyal medya paylaşımları ve haber içerikleri değerlendirilmiştir. Ayrıca, yaşanan afet sonrasında AFAD, Türk Psikologlar Derneği, Sosyal Hizmet Uzmanları Derneği ve Türkiye Barolar Birliği web siteleri ve sosyal medya hesaplarında yapılan paylaşımlar medya ve etik çerçevesi içerisinde incelenmiştir.

\subsection{Ekim 2020 İzmir Seferihisar Depremi Örneği}

30 Ekim 2020 tarihinde, Türkiye saati ile 14:51'de merkez üssü Ege Denizi, Seferihisar (İzmir) açıklarında olan Mw 6.6 büyüklügünde bir deprem meydana gelmiş ve bu deprem sonucunda 117 kişi hayatını kaybetmiştir (URL 27). Geçmişte yaşanmış afetlerde olduğu gibi İzmir Seferihisar Depremi de Türkiye afet yönetim sistemi için bir sınav niteliği taşımıştır. Afet yönetim sistemi içerisinde bulunan tüm sektörler ve aktörler için önemli gelişmelerin yaşandığı İzmir Seferihisar Depremi, medya ve etik açısından da kritik gelişmelerin yaşandığı bir deneyim olmuştur.

AFAD'ın yaşanan deprem sonrası resmi internet sitesini, Twitter ve Instagram gibi sosyal medya hesaplarını etkin bir şekilde kullandığı söylenebilir. Nitekim söz konusu platformlarda paylaşılan içeriklerde, depremden sonra yapılması gerekenler, uyarılar, etkilenen kişilerin yardım 
hizmetlerine ulaşabilmesi için yönlendirmeler ve yapılan çalışmalar ile ilgili genel paylaşımlar olduğu görülmektedir. Örnek olarak; AFAD'ın depremden hemen sonra resmi Twitter ve Instagram hesaplarından yaptığı paylaşımlarda; iletişim altyapısının kesilmemesi adına internet tabanlı uygulamaların veya SMS kullanımının tercih edilmesi, depremden sonra hasarlı binalara girilmemesi, acil durum araçlarının hızlı geçişi için yolların boş bırakılması, sosyal medyada oluşabilecek dezenformasyon içerikli paylaşımlara itibar edilmemesi, doğru bilgi için resmi kaynakların takip edilmesi, deprem bölgesine yardımları ile ulaşmak isteyen vatandaşların hangi tür yardımları yapacağı ve yardım malzemelerini nasıl göndereceği konusunda yönlendirmede bulunduğu görülmektedir. AFAD resmi internet sitesinde ise, deprem olduğu andan itibaren yaşanan olay, yapılan çalışmalar ve vatandaşların dikkat etmesi gereken hususlar ile ilgili 81 duyuru yayınlamıştır. Bu duyuruların 66'sı depremi takip eden 7 gün içinde yapılmıștır. (URL 28).

Afetlerde doğru bilginin tek elden yayınlanması; halkın bilgilendirilmesi, bilgi kirliliğinin önüne geçilmesi, kurum ve kuruluşların koordine edilmesi noktasında kritik bir öneme sahiptir. Bu sebeple AFAD' in sosyal medya hesaplarını etkin bir şekilde kullanması afet yönetiminde iletişimin etkin şekilde sağlanması anlamında önem arz etmektedir. Sosyal medya platformlarının geniş bir kullanıcı kitlesinin olması, afet ve acil durumlarda birçok avantaj sunmasına karşın, bilgi kirliliği oluşturma, yanlış bilgilerin yayınlanması, yapılan paylaşımlarda etik hususlara dikkat edilmemesi gibi nedenlerden ötürü dezavantajlı durumların oluşmasına sebebiyet verebilmektedir.

Afetler medya organları için çoğu zaman ilgi çekici bir konu olmuştur. Bu durum İzmir Seferihisar Depreminde de değişmemiş, depremin hemen sonrasında medya organları bölge ile ilgili bilgileri halka sunmaya başlamışlardır. Diğer taraftan bölgede yaşayan vatandaşlar da kendi sosyal medya hesaplarından yaşanan afet ile ilgili gelişmeleri, yardım çalışmalarını ve çeşitli bilgilendirmeleri yayınlamaya başlamışlardır. Gerek medya kuruluşları ve çalışanları gerekse sosyal medya kullanıcılarının yayınladığı haber içeriklerinde dikkatleri çeken ilk nokta, depremden sonra yapılan arama kurtarma çalışmalarının tüm açıklığı ile topluma sunulması olmuştur. 6 gün süren arama kurtarma çalışmaları (URL 29), tüm gerçekliği ile halka kesintisiz yayınlar ile aktarılmıştır (URL 30). Arama kurtarma çalışmaları ve enkaz görüntülerinin medya kuruluşları aracılığı ile ulusal kanallarda ve vatandaşlar aracılığıyla da sosyal medya platformlarında paylaşıma açılması, tüm toplumun bu görüntülere maruz kalmasına sebep olmuştur. Bahsedilen kurtarma çalışmalarının etkileyici görüntülerine tüm vatandaşlar herhangi bir kısıtlama olmaksızın çoğu sosyal medya platformundan ulaşabilmektedir. Arama kurtarma çalışmalarında yaralı bedenlerin gösterilmesinin, haber verme kaygısının önüne geçerek duygu sömürüsüne dayanması, toplumda travma yaratan bir etki bırakmıştır (URL 31). Sadece afeti yaşayanların değil, medyadan takip edenlerin de afetten etkilenebildiği gerçeğiyle (URL 14), IASC, travmatik hikâye ve görüntülerin afet ve acil durumlarda yayılmasının tüm toplumda olumsuz etki bırakabileceğini belirtmiştir. Bu nedenle, yapılan çalışmalar ile ilgili dehşet verici görüntülere tüm vatandaşların rahatlıkla ulaşabilmesi, sosyal medyanın olumsuz yanlarına verilebilecek ilk örnek olarak değerlendirilebilmektedir.

Arama kurtarma ve insani yardım çalışmalarında çocukların, sosyal medya platformlarında daha çok gündemde olduğu görülmektedir. Bu durumun sebebi çocukların ortak değer olarak görülmesi, korunmaya muhtaç varlıklar olarak tanımlanması ve medya organlarında haber değerinin yüksek olması olarak değerlendirilebilir. Çocukların medya içeriklerinde kullanılması sürecinde çocuklara dair algı, belirleyici bir faktördür. Çocukların "yetişkinliğe erişmemiş", "yarım", "eksik" olarak algılanması, onların birey olduğunun görmezden gelinebilmesine, bu sebeple kendilerine ait fikir, sınır ve mahremiyet gibi özel alanlarının yok sayılabilmesine zemin hazırlayabilmektedir (URL 31). Özellikle kurtarma çalışmalarında, çocukların medyada büyük bir yer kaplaması, onların mahremiyetlerinin ihlal edildiği anlamına gelebilmektedir. TGC, çocuk haberleri konusunda, haber içeriklerinde çocukların mahremiyetlerine saygı duyulması gerektiği belirtilmiştir (URL 23). Kurtarma çalışmalarının canlı yayınlanması, vatandaşların cep telefonları 
aracıllğı ile bölgeden görüntü alabilmesi, bir çocuğun belki de en zor anında ve bilinç dışı bir halde iken, kendisinin veya velisinin rızası alınmadan görüntülerinin alınması, onların mahremiyetlerinin ihlal edildiği anlamına gelebilmektedir. Ayrıca BBC'nin “Çocuklara İlişkin Yayıncılık İlkeleri" nde ve çocukların medyada temsiline yönelik yapılan kılavuz çalışmalarının birçoğunda ortak bir kanaat olarak; çocuk görüntülerinin haber içeriklerinde kullanılmasının rızaya bağlı olduğu belirtilmektedir.

Afetlerde medya da karşılaşılan başka bir unsur, etkilenen insanların umutsuz ve çaresiz insanlar olarak yansıtılmasıdır. Depremden etkilenen insanlar kurtarma ve yardım çalışmalarında, dramatize edilerek, duygu sömürüsüne dayanan hikayeleștirme çabaları ile tüm topluma umutsuz objeler olarak yansıtılması, bir yandan onurlu yaşam hakkının ihlali olarak değerlendirilebilirken, diğer yandan toplumun genelinin bu görüntülere maruz kalıp psikolojik olarak olumsuz etkilenmesine sebep olabilmektedir. Konu ile ilgili ICRC, yardım kuruluşlarının çalışmalarında afetten etkilenen insanların umutsuz kurbanlar değil, onurlu bireyler olarak gösterilmesini tavsiye etmektedir (URL 16).

Yaşanan afette, hak temelli bakış açısından uzak bir şekilde, enkaz görüntülerinin sansürlenmeden yayınlanması, afetten etkilenen insanların özel hayatlarının gizliliğinin ihlali ve kişisel verilerin korunması kanununa göre suç teşkil edebilmektedir. Diğer taraftan, çocuklar söz konusu olduğunda çocuk dostu habercilik anlayışının dışında üretilen içerikler, ülkemizin de taraf olduğu BM Çocuk Hakları Sözleşmesi'ne de aykırılık teşkil etmektedir (URL 31). İzmir Seferihisar Depremi ile ilgili bugün bile çoğu sosyal medya platformunda ulaşılabilen enkaz altı görüntüleri, enkazın altındaki çocuğa mikrofon uzatılması, içeriklerin ticari malzeme haline getirilmesi ve çocukların nesneleştirilerek, fiziksel ve psikolojik iyilik halleri gözetilmeden üretilen içerikler, hak ihlalleri olarak değerlendirilebilmektedir. Diğer taraftan örnek olarak, depremden 58 ve 91 saat sonra kurtarılan kişilerin, yıllar boyunca sosyal medya platformlarında kalacak görselleri, unutulma hakkının da önüne geçen bir durum olarak değerlendirilebilir. Bu durum afetten etkilenen insanların yas sürecini zayıflatırken, yıllar sonra aynı görüntülerle yeniden karşılaşması, anıların canlanması noktasında tetikleyici bir unsur olabilmektedir.

Deprem sonrasında, Sosyal Hizmet Uzmanları Derneği İzmir Şubesi'nin "shuderizmir" isimli ve Türk Psikologlar Derneği İzmir Şubesinin "tpdizmir" isimli Instagram hesaplarında yer alan "Afet Sonrası Saha Etiği" başlıklı paylaşımda; bireylerin izninin alınmadan, kimliğini açığa çıkaracak şekilde yayın yapmanın uygun olmadığı, görüntüsü alınan bireylerin, yapılacak haberin sonuçları hakkında bilgilendirilmesi, haberi daha ilgi çekici yapmak adına afetten etkilenenlerin haklarının ihlal edilmemesi gereklilikleri üzerinde durulmuştur. Diğer taraftan İstanbul Barosunun "istbarosu" isimli Instagram sayfasında, afetten etkilenen çocuğun tanınmasına sebep olacak biçimde yapılan habercilik, Basın Kanun'una göre suç ve çocuk hakkı ihlali olarak değerlendirilmiştir.

Deprem sonrası yürütülen arama kurtarma ve yardım çalışmalarında hem medya kuruluşları hem de sosyal medya araçları ile vatandaşlar tarafından etik açıdan yanlış olarak nitelendirilebilecek haber içerikleri ve paylaşımlar yapılmıştır. Söz konusu içerikler ve paylaşımlar; kişileri mağdur, umutsuz ve çaresiz objeler olarak göstermekte, kişilerin rızası ve bilgisi dahilinde olmadığı için özel hayatın gizliliğini ve mahremiyeti ihlal etmekte, dehşet verici görüntüler tüm toplumun psikolojisini etkilemekte ve afetten etkilenen insanların görüntülere sürekli maruz kalıp iyileşme sürecini yavaşlatabilmektedir. Özellikle çocukların söz konusu haklarının görmezden gelinip, dramatize edilerek araçsallaştırılması ile gündeme gelen afet ve acil durumlarda medya araçlarının kullanımında dikkat edilmesi gereken husus, üretilecek haber içerikleri veya paylaşımlarda, çocuğun yüksek yararı ve kamu yararı arasında seçim yapabilmektir. Bariz bir kamu yararının bulunduğu durumlarda çocuk görüntülerinin, yine de hassasiyetler göz ardı edilmeden, paylaşılması normal karşılanabilirken, kamu yararının olmaması durumunda konu tartışmaya kapalı olarak değerlendirilmekte ve çocuk görsellerinin, çocuğun yüksek yararı gereği 
medyada yer almaması gerekmektedir (URL 32). Deprem sonrasında, son saatlerde kurtarma ekiplerinin özverili çalışmaları sonucu çıkarılan çocukların, kurtarma görüntülerinin medyada yer almasında herhangi bir kamu yararı bulunmadığı gibi çocuğun yüksek yararı da söz konusu olmadığından etik açıdan yanlış bir tutum olarak değerlendirilebilir. Diğer taraftan bu görüntüler, kamuoyunun dikkatini kurtarma çalışmalarına çekerken, yaşanan doğa olayının, insan faaliyetlerinin de etkisiyle can ve mal kayıpları gibi sonuçları düşünüldüğünde, neden bir afete dönüştüğü konusunun dikkatlerden kaçmasına sebep olmuştur.

\section{SONUÇ VE ÖNERILER}

Teknolojinin hızla gelişmesiyle beraber, medya sektörü de gelişim göstermekte ve geleneksel medyadan, dijital medyaya hızlı bir geçiş olmaktadır. Dijital medyadaki bu gelişim, sadece medya profesyonellerinin değil, aynı zamanda internet erişimi bulunan herkesin sektör içinde yer almasına olanak tanımaktadır. Bu kalabalık ortam ise, kriz zamanlarında yanlış uygulamaların gerçekleşmesini beraberinde getirmektedir. Can ve mal kayıpları yaratan afetler, gerçekleştiği bölgeye ve büyüklügüne göre toplumsal bir şok etkisi yaratabilme potansiyeline sahiptir. Bu sebeple bütünleşik afet yönetim sistemi içerisinde yer alan tüm aktörlerin, afetlerde rutin çalışma koşullarından çıkması ve afeti deneyimleyen toplumun mümkün olan en kısa sürede normal yaşantısına dönmesi için kriz durumuna uygun faaliyet gösterebilmesi gerekmektedir. Söz konusu aktörlerden hem geleneksel medyanın hem de sosyal medyanın kalabalık ve esnek yapısı, afetler sırası ve sonrasında, bilginin hızla yayılması, farkındalığın oluşturulması, yardımlaşmayı ve dayanışmayı arttırması gibi birçok olumlu katkısı bulunmaktadır. Diğer taraftan bu işlevsellik, yönetimi ve kontrolü açısından hassasiyet ile yaklaşılması gereken afetlerde yeni, düzenlenmesi gereken ve durumlara özgü kurallara ihtiyaç duyulan alanlar yaratmaktadır. Daha çok geleneksel medya alanına yönelik olarak ülkelerin ve hatta kuruluşların haber içeriklerinde etik konusunda birçok düzenlemesi bulunmaktadır. İlgili düzenlemeler, haber içerikleri konusunda genel bir çerçeve oluştururken, afetler özelinde düzenlemeler bulunmamaktadır. Öte yandan, konuya sosyal medya açısından bakıldığında, afetlerde içerik paylaşımları konusunda düzenlemelerin yetersiz kaldığı görülmektedir. Bunun sonucu olarak afet dönemi haber içeriklerinde ve paylaşımlarda kişisel haklar, mahremiyet, incinebilir gruplar konusunda hassasiyet göz ardı edilebilmekte, paylaşımların toplumda yaratacağı olumsuz etkiler önemsizleşmekte, daha duygusal içerik ve manipülatif bir habercilik tutumuyla toplumsal algı gerçekleşen olayın daha önemsiz bir boyutuna yönlendirilebilmekte, yapılan haberler ve paylaşımlar sebebiyle gündem yaşanan afetten çıkıp, tarafların oluştuğu toplumsal bir karmaşaya dönüşebilmektedir.

Afetlerin ilk ve en temel odak noktası insan hayatıdır. Bu sebeple ilgili alanda hizmet veren tüm sektörlerin insan hayatının korunması ve yaşanan afetten en az zararla çıkılması gibi amaçları bulunmaktadır. Bu odak noktası ve amaç dışında icra edilen tüm faaliyetlerin asıl olanı gözden kaçırmak gibi bir riski bulunmaktadır. Medya için afet ve acil durumlar sansasyonel, ilgi çekici, karmaşık, ranta açık bir alan olarak değerlendirilebilmekte, bunun sonucunda asıl sorumluluk sahası olan doğru, açık ve güvenilir bilginin halka ulaştırılması konusunda zorluklar yaşanabilmektedir. Çalışmada İzmir Seferihisar Depremi sonrası ekranlara yansıyanlar olumlu ve olumsuz olarak iki kısımda incelenmiştir. Medyanın hızlı ve etkili bir biçimde dayanışma ortamını sağlaması, bölge halkının yaşanan afetle ilgili önemli bilgilere ulaşmasını sağlaması ve sorumlu vatandaşlık bilinciyle mağduriyet içinde olan vatandaşların kaynaklarla buluşmasını sağlaması gibi olumlu katkıları olmuştur. Diğer taraftan arama kurtarma ve yardım çalışmalarında medya ve etik konusunda içerikte değinilen ulusal ve uluslararası metinlerden bağımsız olarak, mahremiyet, özel hayatın gizliliği, unutulma hakkı, sansasyonel haberlerden kaçınma, habere konu olan kişilerin açık rızası gibi konuların göz ardı edildiği, özellikle çocuklar üzerinden yapılan dramatik haber içeriklerinin ekranlarda yer aldığı, mucize kurtuluşların hipnotize edici etkisinin asıl nedenleri unutturduğu bir medya performansının olduğunu söylemek mümkündür. 
Sonuç olarak, geleneksel medya ve sosyal medyanın afet öncesi, sırası ve sonrasında toplumun afet direncinin oluşması aşamasında pozitif anlamda daha güçlü bir aktör olabilmesi için, yeni hukuki düzenlemelerin hayata geçirilmesi, medya araçlarının kullanımı konusunda hem güncel hem de tüm medya sektörünü kapsayan etik kılavuzlar geliştirilmesi, tüm afet süreçlerine yönelik özel bir yönetim anlayışının ve planının hazırlanması ve konuyla ilgili tüm tarafların farkındalık seviyelerinin geliştirilmesi kaçınılmaz bir ihtiyaç haline gelmiştir.

\section{KAYNAKLAR}

Akdağ, M ve Taşdemir, E. (2006). Krizden Çıkmanın Yolları: Etkin Bir Kriz İletişimi. Selçuk İletişim, 4(2), 141-157. Retrieved from https://dergipark.org.tr/tr/download/article-file/177980

Alexander, D. E. (2014). Social Media in Disaster Risk Reduction and Crisis Management. Sci Eng Ethics 20, 717-733. DOI 10.1007/s11948-013-9502-z

Baechler, N. C. (2018). Afet Risk ve Zarar Azaltmada İletişim Stratejisinin Rolü. 2ND International Symposium on Natural Hazards and Disaster Management içinde, Sakarya. https://www.ishad.info/PastConferences/ISHAD2018/ISHAD2018/papers/A1.1-ISHAD2018ID140.pdf

Baltaş, A. (2015). Akılsız Duyguların Cezasını Kararlar Çeker, Akıllı İnsanlar Neden Yanlış Kararlar Verir? Remzi Kitapevi.

Bird, D., Ling, M., \& Haynes, K. (2012). Flooding Facebook- the use of social media during the Queensland and Victorian floods. Australian Journal of Emergency Management, 27(1), 27-33.

Boyd, D. M. \& Ellison, N.B. (2008). Social Network Sites: Definition, History, and Scholarship. Journal if Computer-Mediated Communication, 13, 210-230. doi:10.1111/j.1083-6101.2007.00393.x

Coombs, W. T. (2015). Ongoing Crisis Communication Planning, Managing, and Responding. SAGE Publications.

Crowe, A. (2011). The social media manifesto: a comprehensive review of the impact of social media on emergency management. Journal of Business Continuity \& Emergemcy Planning, 5(1): 409-420.

Çakır, C. (2017). Sosyal Medyada Kişilik Hakları İhlalleri ve Koruma Yolları. Akdeniz Üniversitesi Hukuk Fakültesi Dergisi, 7(2), 155-193.

Dufty, N. (2012). Using Social Media to Build Community Disaster Resilience. The Australian Journal of Emergency Management, 27(1), 40-45. https://knowledge.aidr.org.au/media/2501/ajem-27-01-11.pdf

Erol, G. (2009). Medya ve etik: İnternet haberciliğinde nesnellik, etik ilkelerin içeriği, uygulamadaki sorunlar ve televizyon haberciliği ile karşılaştırılması, Fırat Üniversitesi İletişsim Fakültesi Medya ve Etik Sempozyumu, 07-09 Ekim 2009, Elazı̆̆.

Fraustino, J., Liu, B. F. \& Jin, Y. (2012). Social Media Use during Disasters Final Report to Human Factors/Behavioral Sciences Division, Science and Technology Directorate, U.S. Department of Homeland Security.

https://www.start.umd.edu/sites/default/files/files/publications/START_SocialMediaUseduringDisaster s_LitReview.pdf

Fraustino, J. Liu, B. F. \& Jin, Y. (2018). Social Media Use during Disasters. L. Austin \& Y. Jin (Eds.) Social media and crisis communication (pp. 283-295). Routledge.

Gao H., Wang X., Barbier G., Liu H. (2011) Promoting Coordination for Disaster Relief - From Crowdsourcing to Coordination. In: Salerno J., Yang S.J., Nau D., Chai SK. (eds) Social Computing, Behavioral-Cultural Modeling and Prediction. SBP 2011. Lecture Notes in Computer Science, vol 6589. Springer, Berlin, Heidelberg. https://doi.org/10.1007/978-3-642-19656-0_29 
Houston, J. B., Hawthorne, J., Perreault, M. F., Park, E. H., Hode, M. G., Halliwell, M. R., ... Griffith, S. A. (2014). Social Media and Disasters: Functional Framework for Social Media Use in Disaster Planning, Response, And Research. Disasters, 39(1), 1-22. doi:10.1111/disa.12092

Kapur, G. B., Bezek, S. \& Dyal, J. (Eds.). (2016). Effective Communication during Disaster Making Use Of Technology, Media, and Human Resources. Apple Academic Press Inc.

Karaman, Z. T. (2017). Afet Yönetimine Giriș ve Türkiye'de Örgütlenme. Z. T. Karaman ve A. Altay (Eds.), Bütünleşik Afet Yönetimi (s. 1-39) içinde. İzmir: Birleşik Matbaacılık.

Lobb, A., Mock, N., \& Hutchinson, P. L. (2012). Traditional and Social Media Covarage and Charitable Giving Following the 2010 Earthquake in Haiti. Prehospital and Disaster Medicine, 27(4), 319-324, DOI: $10.1017 /$ S1049023X12000908

Lovari, A. \& Bowen, S. A. (2019). Social Media in Disaster Communication: A Case Study of Strategies, Barriers, and Ethical İmplications. Journal of Public Affairs, e1967. DOI:10.1002/pa.1967

Merchant, R. M., Elmer, S. \& Lurie, N. (2011). Integrating Social Media into Emergency-Praparedness Efforts. N Engl J Med, 365, 289-291. DOI: 10.1056/NEJMp1103591

Nalbantoğlu, S. (2018). Bir Temel Hak Olarak Unutulma Hakkı. Türkiye Adalet Akademisi Dergisi, (35), 583605. Retrieved from https://dergipark.org.tr/tr/pub/taad/issue/52647/693627

Orsburn, E. M. (2012). Social media business equation: Using online connections to grow your bottom line. Course Technology PTR.

Öztürk, Ş. (2015). Sosyal Medyada Etik Sorunlar. Selçuk İletişim, 9(1), 287-311. Retrieved from https://dergipark.org.tr/tr/pub/josc/issue/19031/201143

Peary, B. D. M., Shaw, R. \& Takeuchi, Y. (2012). Utilization of social Media in the East Japan Earthquake and Tsunami and its Effectiveness. Journal of Natural Disaster Science, 34(1), 3-18. D0I:10.2328/jnds.34.3

Postman, J. (2008). SocialCorp: Social media goes corporate. New Riders.

Qadir, J., Ali, A., Rasool, R., Zwitter, A., Sathiaseelan, A. \& Crowcroft, J. (2016). Crisis Analytics: Big DataDriven Crisis Response. Journal of International Humanitarian Action, 1(12). DOI 10.1186/s41018-0160013-9

Rodriquez, H., Diaz, W., Santos, J. M. \& Aguirre, B. E. (2007). Communicating Risk and Unceartainty: Science, Technology, and Disaster at The Crossroads. H. Rodriguez, E. L. Quarantelli \& R. R. Dynes (Eds.), Handbook of Disaster Research (pp. 476-489). Springer.

Sarıŏlu, E. B. (2020). Yalan Haber, "Post-Truth” Kavramı ve Medya Üçlemesi: Geçmișten Günümüze Gündem Belirleyen Örnekler. Insan ve Toplum Bilimleri Araştırmaları Dergisi, 9(1), 377-397. Retrieved from http://www.itobiad.com/tr/issue/53155/642988

Tenikler, G. (2012). Afet Yönetiminde Etik Sorumluluk. G. Ürcan Editör (Yay. haz.) Etik içinde (s. 249-282). İzmir: İde Yönetişim-Yayıncılık.

Toker, H. (2017). Doğal Afetler, İletişim ve Medya. Z. Toprak Karaman ve A. Altay (Eds.), Bütünleşik Afet Yönetimi içinde (s. 253-278). İzmir: Birleşik Matbaacılık.

Türkel, N. (2010). Özel Hayatın Gizliliğini İhlal Suçu [Yüksek Lisans Tezi]. Dokuz Eylül Üniversitesi. https://acikerisim.deu.edu.tr/xmlui/bitstream/handle/20.500.12397/10603/270741.pdf?sequence=1\&i sAllowed=y

UNICEF. (2019). Afet ve acil durumlarda psikososyal destek hizmetleri saha çalışanları için el kitabı. Ankara: UNICEF Türkiye Temsilciliği. 
URL 1, https://cred.be/sites/default/files/CRED-Disaster-Report-Human-Cost2000-2019.pdf (Last Accessed: 20. 05. 2021)

URL 2, https://wearesocial.com/uk/blog/2020/01/digital-2020-3-8-billion-people-use-social-media (Last Accessed: 08.05.2021)

URL 3, https://mashable.com/2010/01/20/social-media-lessons-haiti/ (Last Accessed:15.01.2021)

URL 4, https://www.balblawyers.com/images/BoggsJuly10reprint.pdf (Last Accessed: 23.05.2021)

URL 5, https://www.sdr.gov/docs/SDRGrandChallengesforDisasterReduction.pdf (Last Accessed: 21.06.2021)

URL 6, https://www.afad.gov.tr/aciklamali-afet-yonetimi-terimleri-sozlugu (Son Erişim: 12.12.2020)

URL 7, https://www.emdat.be/publications?page=1 (Last Accessed: 10.05.2021)

URL

8,

https://www.pewinternet.org/wpcontent/uploads/sites/9/media/Files/Reports/2013/PIP_Social_networking_sites_update_PDF.pdf (Last Accessed: 20.12.2020)

URL 9, https://wearesocial.com/uk/blog/2021/01/digital-2021-the-latest-insights-into-the-state-ofdigital/ (Last Accessed: 02.11.2021)

URL 10, https://datareportal.com/reports/digital-2021-turkey?rq=turkey (Last Accessed: 07.07.2021)

URL 11, https://crystalwashington.com/the-role-of-social-media-during-natural-disasters/ (Last Accessed: 10.01.2021)

URL 12, https://www.afad.gov.tr/elazigda-meydana-gelen-68-buyuklugundeki-deprem-hakkinda (Son Erișim: 16. 12. 2020)

URL 13, https://www.afad.gov.tr/izmir-seferihisar-depremi--duyuru-1-30102020---1620 (Son Erişim: 16.12.2020)

URL 14, https://www.ipkb.gov.tr/wp-content/uploads/2018/10/Afetlerde-Psikolojik-ilkyardim-1.pdf (Son Erişim: 20.07.2021)

URL 15, https://interagencystandingcommittee.org/system/files/iasc_mhpss_guidelines_turkish.pdf (Son Erişim: 06.07.2021)

URL 16, https://www.hayatadestek.org/wp-content/uploads/2016/12/icrc-davranis-kurallari.pdf (Son Erişim: 06.07.2021)

URL 17, https://www.unicefturk.org/public/uploads/files/UNICEF_CocukHaklarinaDairSozlesme.pdf (Son Erişim: 07.07.2021)

URL 18 , https://www.unicef.org/turkey/media/3966/file/\%C3\%870CUK\%20HAKLARI\%20VE\%20GAZETEC\%C 4\%B0L\%C4\%B0K\%20UYGULAMALARI\%20HAK\%20TEMELL\%C4\%B0\%20PERSPEKT\%C4\%B0F.pdf (Son Erişim: 07.07.2021)

URL 19, https://childhub.org/sites/default/files/library/attachments/63 153 EN original.pdf (Last Accessed: 08.07.2021)

URL 20, https://spherestandards.org/wp-content/uploads/Sphere-Handbook-2018-EN.pdf (Son Erişim: 07.07.2021) 
URL 21,

https://reliefweb.int/sites/reliefweb.int/files/resources/0F0E79A7DB1530EFC1256F3200543BB2-

EMA Psychology Disasters.pdf (Last Accessed: 08.07.2021)

URL 22, https://www.ifj.org/fileadmin/user_upload/Global_Charter_of_Ethics_EN.pdf (Last Accessed: 08.07.2021)

URL 23, https://www.tgc.org.tr/bildirgeler/t\%C3\%BCrkiye-gazetecilik-hak-ve-sorumluluk-bildirgesi.html (Son Erişim: 08.07.2021)

URL 24, https://www.tgc.org.tr/bildirgeler/medya-ve-cesitlilik-kilavuzu.html (Son Erişim: 08.07.2021)

URL 25, https://www.unicef.org/eca/media/ethical-guidelines (Last Accessed: 10.07.2021)

URL 26, https://izmir.afad.gov.tr/kurumlar/izmir.afad/TAMP_Izmir-2021_Revize.pdf (Son Erişim: 10.11.2021)

URL 27, https://www.afad.gov.tr/izmir-seferihisar-depremi-duyuru-81-26112020---2100 (Son Erișim: 17. 12. 2020)

URL 28, https://www.afad.gov.tr/duyurular (Son Erişim: 18.12.2020)

URL 29, https://www.afad.gov.tr/izmir-seferihisar-depremi-duyuru-67-04112020---2240, (Son Erişim: 17.12.2020)

URL 30, https://tr.sputniknews.com/columnists/202011161043232166-turkiyede-medya-depremhaberciliginde-iyi-bir-sinav-verebildi-mi/ (Son Erişim: 20.03.2021)

URL 31, https://www.stgm.org.tr/cocuklar-icin-degil-cocuklarla-calisma-anlayisini-yayginlastirmak-gerek (Son Erişim: 20.03.2021)

URL 32, https://www.newslabturkey.org/deprem-doneminde-sorumlu-ve-etik-habercilik/ (Son Erișim: 14.01.2021)

Zincir, O. ve Yazıcı, S. (2013). Kriz Yönetimi ve Afetlerde Sosyal Medya Kullanımı. I.Ü. Siyasal Bilgiler Fakültesi Dergisi. 49, 65-82. https://dergipark.org.tr/tr/download/article-file/5714 